\title{
Pendidikan Karakter Melalui Pengembangan Model Pembelajaran RKCK (Rasa Karsa Cipta Karya)
}

\author{
Yeni Rachmawati \\ yeniedu@yahoo.com \\ PGPAUD FIP Universitas Pendidikan Indonesia
}

\begin{abstract}
Abstrak
Saat ini, globalisasi adalah sebuah keniscayaan dalam hidup kita. Semua orang di dunia, termasuk bangsa Indonesia membutuhkan strategi terbaik agar mampu bersaing dengan era globalisasi. Pendidikan sebagai salah satu unsur dalam kehidupan manusia telah menjadi posisi kunci untuk mengantisipasi gelombang globalisasi. Ide-ide dan konsep pendidikan yang baru diperlukan untuk memperkuat identitas bangsa, melestarikan kearifan lokal, mampu menjawab tantangan modern dan memiliki dasar yang baik untuk membangun karakter. Salah satu hal yang dapat dilakukan adalah dengan mengembangkan model pembelajaran yang berbasis pada kearifan lokal dari "RKCK (Rasa-Karsa-Cipta-Karya).Model ini dianggap sebagai salah satu solusi untuk menjawab permasalahan. Beberapa keunggulan dari model pembelajaran berbasis Model RKCK adalah bahwa model ini lahir dari filsafat Indonesia. Dengan demikian, Model Pembelajaran RKCK memiliki kekuatan untuk melahirkan kembali nilai-nilai semangat Indonesia. Konsep model RKCK sebenarnya bukanlah ide baru, tetapi telah ada sejak lama. Penelitian lebih lanjut diharapkan dapat membangun kembali filosofi model pembelajaran dan dapat mengaplikasikannya dalam kehidupan nyata. Model RKCK bersifat holistik dan sistem implementasinya terintegrasi, sehingga tidak hanya aspek kecerdasan saja tetapi juga aspek sosial emosional dan kecerdasan spritual yang dapat meningkatkan ketajaman pikiran peserta didik.
\end{abstract}

Kata kunci: Membangun Karakter, Berbasis pada Kearifan Lokal, Kearifan Lokal, Menyeluruh, Terpadu

\begin{abstract}
Nowadays, globalisation is necessity in our life. Everyone in the world, including Indonesian needs the best strategy to compete with it. Education as one element in human life, has became a key position to anticipate this wave. The new idea of education, which is have a concept to strengthen the nation identity, preserve the indigenous wisdom, have a possession to answer the modern challenges and have good foundation to character building, is needed. Furthermore, developing learning model base on indigenous wisdom of " RKCK (Rasa-Karsa-Cipta-karya)", will fix a board in this article. This Model considered to be one alterative solutions which is need to answer the problems. The are several advantages of Learning Model Base on RKCK. One of them is this model was born from Indonesian philosophy. Thus, the RKCK Learning Model have a power to reborn the values on Indonesian spirit. The concept of RKCK model is not the new idea, but it has been existing in their life. Moreover, this further research will rebuild this filosophy to a
\end{abstract}


model of learning and making the way to implement. Besides that, The model of RKCK is insist the holistic and integrated implementation system. So that not only cognition intelligence but also emotional-social and spriritual intelligence will raise on student mind.

Keywords: character building, RKCK Base Learning, indigenous wisdom, holistic,integrated

\section{Pendahuluan}

Beberapa persoalan pendidikan yang dihadapi masyarakat Indonesia saat ini diantaranya adalah orientasi pendidikan yang cenderung kognitif, rendahnya kecerdasan rasa yang ditandai dengan semakin meningkatnya kekerasan dan kriminalitas di masyarakat, serta masih rendahnya elaborasi kekayaan kultur bangsa sendiri diungkapkan Surakhmad (2009) bahwa "tekanan yang berlebihan pada pembelajaran yang bersifat skolastik dan akademik telah mengorbankan kepentingan pendidikan yang bersifat menyuruh".

Globalisasi adalah arus zaman yang tidak dapat dihindari, namun membutuhkan strategi dan antisipasi yang sangat mendasar dalam menjalaninya. Jika tidak ditangani dengan baik, masyarakat Indonesia akan kehilangan jati diri dan akan selalu menjadi "pengekor". Pendidikan sebagai upaya untuk membantu anak didik dalam menjalani kehidupan, memiliki tugas penting untuk mengantisipasi persoalan ini.

Menindaklanjuti persoalan tersebut, Indonesia sebagai negara berkembang sangat membutuhkan rumusan konsep pendidikan yang memiliki jati diri kebangsaan, bersifat holistikintegratif sekaligus dapat menjawab kebutuhan akan pentingnya pembinaan budi pekerti luhur (character building) sejak dari pendidikan anak usia dini.

Berdasarkan latar belakang tersebut, peneliti sangat tertarik untuk menggali lebih dalam tentang konsep kehidupan "Rasa- Karsa-Cipta-Karya" yang telah dikenal oleh masyarakat Indonesia sejak zaman Sunan Kalijaga. Karena sifatnya yang menyeluruh dan menyentuh seluruh aspek kehidupan individu, Konsep tersebut akan diramu dan dikembangkan menjadi suatu model pembelajaran khas Indonesia. Model pembelajaran RKCK (RasaKarsa-Cipta-Karya) diusung dan disinyalir dapat menjadi salah satu alternatif pilihan yang dapat menjawab kebutuhan tadi.

RKCK (Rasa Karsa Cipta Karya) lahir dari falsafah masyarakat Indonesia sendiri, sehingga memiliki kekuatan untuk mewarnai dan menghidupkan nilai-nilai keindonesiaan dalam implementasinya. Selain itu RKCK menekankan konsep dan implementasi yang holistik dan integratif (mulai dari aspek sosial-emosi-spiritual, konatif, kognitif, dan psikomotorik) sehingga anak didik akan terbiasa untuk mengembangkan kecerdasan rasa dan kecerdasan pikir serta bertindak dalam kehidupan. Model pembelajaran RKCK merupakan suatu inovasi model terbarukan yang akan dipatenkan dan dipubli-kasikan sehingga dikenal masyarakat dunia, sebagai suatu model yang lahir dari falsafah bangsa Indonesia.

\section{Pendidikan Manusia Tujuan Pendidikan adalah "Menjadi Manusia Sejati"}

Pada dasarnya tujuan pendidikan adalah memanusiakan manusia 
atau dengan kata lain membina manusia untuk menjadi manusia sejati yang berbudi pekerti luhur, seimbang jasmani-rohani. Berikut ini akan dikemukakan beberapa pandangan tentang pendidikan humaniora yang mengarah pada pembentukan manusia sejati.

Ledesma (Sardi, 1985) merumuskan bahwa; "pendidikan bertujuan membantu seseorang supaya dapat menggarap hidupnya sendiri, supaya akal budinya berkembang, supaya dapat terlibat dalam tata kemasyarakatan dan dengan demikian dapat semakin mudah mencapai tujuan hidup yaitu bersatu dengan Tuhan". Hal ini mirip dengan tujuan pendidikan yang dikemukakan Mangkunegoro IV, sebagaimana dirumuskan oleh Ki Hajar Dewantara yakni "tujuan pendidikan adalah supaya dapat memajukan kesempurnaan hidup peserta didik yaitu selaras dengan kodratnya, serasi dengan adat istiadat, dinamis, memperhatikan sejarah bangsa dan membuka diri pada pergaulan kebudayaan lain“.

Adapun Driyarkara (1985) merumuskan intisari pendidikan sebagai "pe-manusia-an manusia muda". Akhirnya dapat dikatakan bahwa tujuan pendidikan harus berpuncak pada citra manusia sejati. Pendidikan harus memfasilitasi perkembangan individu secara utuh atau dengan kata lain teroptimalkannya keseluruhan potensi masing-masing individu yang berbeda satu sama lain. Hal ini menunjukkan bahwa proses pendidikan berpuncak pada adanya "perubahan" dalam diri peserta didik. Perubahan itu terutama menyangkut sikap terhadap kehidupan yang dialaminya.

Pendidikan tidak saja memberikan pengetahuan yang bersifat intelektual, tetapi mengajak individu untuk menghayati dan menginternalisasi berbagai ekspresi kemanusiaan dengan berbagai dimensi dalam dirinya. Manusia memiliki banyak potensi jiwa-raga yang harus diperhatikan dan dikembangkan. Pendidikan yang terlalu memusatkan pada satu aspek kemanusiaan akan sangat merugikan kehidupan. Pendidikan adalah wahana untuk membangun dan mengembangkan fisik, mental, dan spiritual sekaligus. Pendidikan pula yang memiliki tugas untuk mengantarkan manusia pada pemaknaan kehidupannya.

\section{Orientasi Tujuan Pendidikan Na- sional Indonesia}

Jika kita mencermati rumusan konsep pendidikan Indonesia yang tertuang dalam undang-undang sistem pendidikan yang telah termuat dalam rumusan Tujuan Pendidikan Nasional dalam pasal 4 Undang-undang Nomor 2 Tahun 1989 tentang Sistem Pendidikan Nasional, yang isinya sebagai berikut.

"Mencerdaskan kehidupan bangsa dan mengembangkan manusia Indonesia seutuhnya, yaitu manusia yang beriman dan bertakwa terhadap Tuhan yang maha Esa dan berbudi pekerti luhur, memiliki pengetahuan dan keterampilan, kesehatan jasmani dan rohani, kepribadian yang mantap dan mandiri serta rasa tanggungjwab kemasyarakatan dan kebangsaan " (Keputusan Mentri Pendidikan dan Kebudayaan Republik Indonesia, 1993)

Upaya pencapaian tujuan pendidikan nasional sebenarnya memuat implikasi yang menyeluruh dalam membina aspek kemanusiaan. Insan pendidikan tidak hanya bertugas dan dituntut untuk piawai dalam mengembangkan aspek kognisi (tertulis; memiliki pengetahuan dan keterampilan) aspek jasmaninya (tertulis; kesehatan jasmani), namun juga pakar dalam mengemban amanah 
dan mengasah aspek rasa atau rohani (tertulis; beriman, bertakwa, berbudi pekerti luhur, kesehatan rohani, kepribadian yang mantap dan mandiri serta tanggungjawab kemasyarakatan dan kebangsaan). Dengan mencermati rumusan tujuan pendidikan nasional di atas sebenarnya yang jauh lebih diutamakan adalah aspek rohani ketimbang aspek kognisi dan jasmani. Dengan demikian, masyarakat Indonesia diharapkan dapat menjalani kehidupannya dengan baik dan sesuai dengan ketetapan Tuhan, baik secara individu maupun dalam bermasyarakat dan bernegara.

\section{Permasalahan}

Ketidakseimbangan Aspek Jasmani dan Rohani dalam Pendidikan di Indonesia

Jika kita cermati rumusan pendidikan nasional di atas, tidak ada permasalahan berarti yang kita temukan. Tujuan pendidikan nasional masih sejalan dengan tujuan pendidikan manusia dan konsep manusia sejati. Persoalannya justru terletak dalam implementasinya. Banyak kritikan tajam berkenaan dengan carutmarutnya pendidikan di Indonesia. Permasalahan-permasalahan ini muncul diantaranya karena disebabkan oleh orientasi praktek pendidikan yang melenceng dari tujuan pendidikan nasional itu sendiri, yaitu tidak seimbangnya pendidikan jasmani dan rohani, kognitif dan afeksi, akal dan budi.

Berkenaan dengan merosotnya mentalitas dan budi pekerti masyarakat, Sindhunata (2000) menjelaskan bahwa

"terjadinya serangkaian kasuskasus tersebut titik berangkatnya bermula dari semesta pendidikan yang gagal dalam membentuk manusia dewasa yang berwatak dan merdeka mandiri. Pendidikan nasional cenderung menonjolkan pembentukan kecerdasan pikir dan menepikan penempaan kecerdasan rasa, kecerdasan budi, bahkan kecerdasan batin. Dari sini lahir manusia-manusia berotak pintar, manusia berprestasi secara kuantitatif akademik, namun tiada berkecerdasan rasa, tiada berkecerdasan budi sekaligus sangat berketergantungan, tidak merdeka mandiri".

Akhir-akhir ini, persoalan meningkatnya kecerdasan pikir yang tidak dibarengi dengan kecerdasan rasa dan moralitas, telah menimbulkan dampak yang cukup besar di Indonesia. Indonesia telah dikenal sebagai negara dengan korupsi terbesar. Para generasi muda mulai kehilangan sopan santun dan meninggalkan budi luhur dan tatakrama. Para mahasiswa dan pelajar gandrung tawuran, narkoba dan pergaulan bebas. Angka ini terus meningkat tajam dan sangat mengkhawatirkan. Masyarakat Indonesia perlu melakukan flash back dan merenungi kembali tentang tujuan dan pemaknaan hidup yang begitu agung dan sudah menjadi bagian hidup dan darah dagingnya sendiri sejak zaman Majapahit dulu.

\section{Posisi Strategis RKCK sebagai solusi permasalahan pendidikan}

Perintis kebangkitan pendidikan Indonesia, Ki Hajar Dewantara (1962), sejak awal kiprahnya telah mencanangkan konsep pendidikan yang menyeluruh. Tidak hanya kecerdasan pikir saja yang dikembangkan namun harus senantiasa mengembangkan keseluruhan potensi manusiawi, meliputi kecerdasan rasa, karsa, cipta, dan karya. Manusia adalah makhluk jasmani dan rohani. Kedua unsur itu harus mendapatkan pendidikan dan pengajaran yang seimbang supaya menjadi manusia seutuhnya. 
Ketika suatu masyarakat hanya menonjolkan satu aspek saja (dalam hal ini aspek kognitif), maka yang terbentuk adalah "masyarakat berkepala besar berhati kerdil" (Sindhunata, 2000) yang kehilangan banyak aspek kemanusiaannya. Model pembelajaran berbasis RKCK (rasa karsa cipta karya) dikembangkan guna menjawab tantangan tadi. Masyarakat perlu satu model pendidikan yang lahir dari kekayaan bangsanya sendiri. Model Pembelajaran RKCK lahir dari falsafah jawa, yang diusung pertama kali oleh Sunan Kalijaga. Falsafah rasa karsa cipta karya merupakan satu kesatuan tindakan yang didasari oleh "hati, pikiran dan tindakan". Tidak hanya merasa, tetapi juga berpikir dan tidak hanya berpikir, tetapi juga melakukan tindakan.

\section{Konsep dan Mekanisme RKCK (Rasa-Karsa-Cipta-Karya)}

Menurut Kamus Besar Bahasa Indonesia (2008), rasa dapat diartikan sebagai: 1) tanggapan indera terhadap rangsangan syaraf, seperti manis, pahit, masam terhadap indera pengecap, atau panas, dingin, nyeri terhadap indera perasa; 2) apa yang dialami oleh badan seperti pedih dan nyeri di perut merupakan gejala sakit lambung; 3) sifat rasa suatu benda seperti gula rasanya manis; 4) tanggapan hati terhadap sesuatu (indera) seperti sedih, bimbang, takut; dan 5) pendapat (pertimbangan) mengenai baik atau buruk, salah atau benar (adil).

Berdasarkan pengertian di atas, kata "rasa" memiliki arti yang melingkupi tanggapan manusia terhadap sesuatu yang dialami, dapat berupa tanggapan pengalaman sistem syaraf (sensoris), fisik/badan (taktil), hati/perasaan (mental-emosional), dan pertimbangan nalar (kognitif). Jika digambarkan dalam bentuk bagan dapat dilihat sebagai berikut:

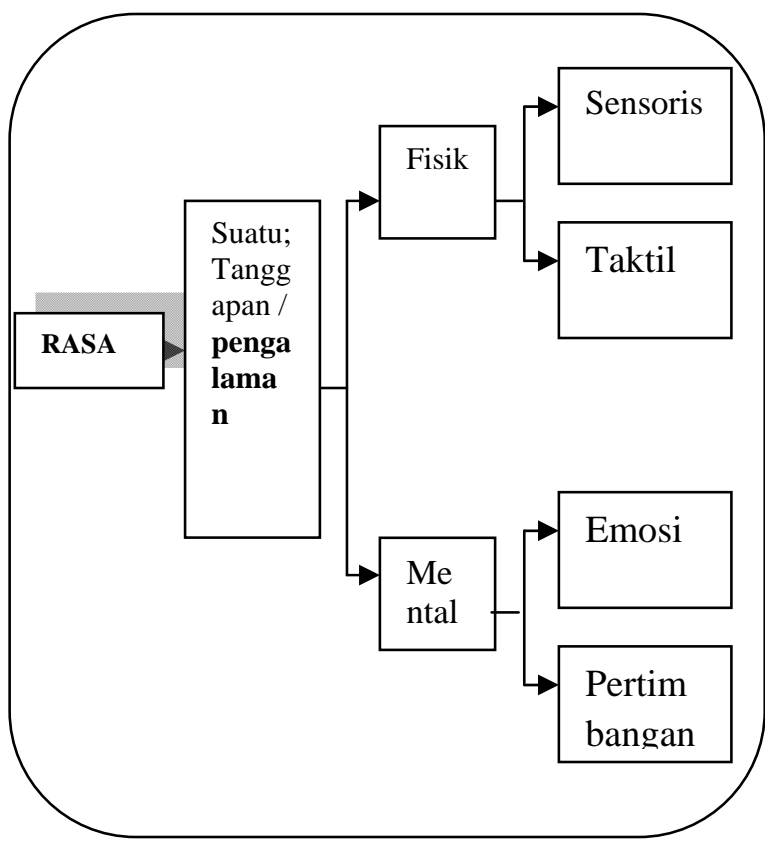

Gambar 1. Struktur Rasa.

1. Definisi Rasa

Aspek Rasa merupakan hal yang abstrak dan sulit dilihat. Bagaimana upaya menstimulasinya adalah dengan cara menstimulasi hal yang konkrit. Stimulasi dilakukan melalui stimulasi sensoris terlebih dahulu kemudian taktil, emosi dan pertimbangan. Semakin tajam tanggapan mereka terhadap pengalaman fisik, semakin dapat membantu menajamkan tanggapan mereka terhadap hal yang lebih abstrak seperti halnya persoalan mental.

Seni merupakan alat yang cukup efektif untuk mengolah rasa. Seni yang sangat kental dengan nilai-nilai estetika dapat membantu individu mengolah daya abstraksi fisik dan mental. Salah satu stimulasi kecerdasan rasa yang cukup efektif dalam mencerdaskan rasa adalah melalui musik. Rachmawati (2005) telah melakukan penelitian tentang pengaruh musik yang menjadi pondasi terbentuknya budi pekerti. Musik juga mempengaruhi fisik dan psikologis individu dengan sangat kompleks. Pengaruh musik terhadap fisik dan mental dapat dilihat melalui gambar 2 berikut ini: 


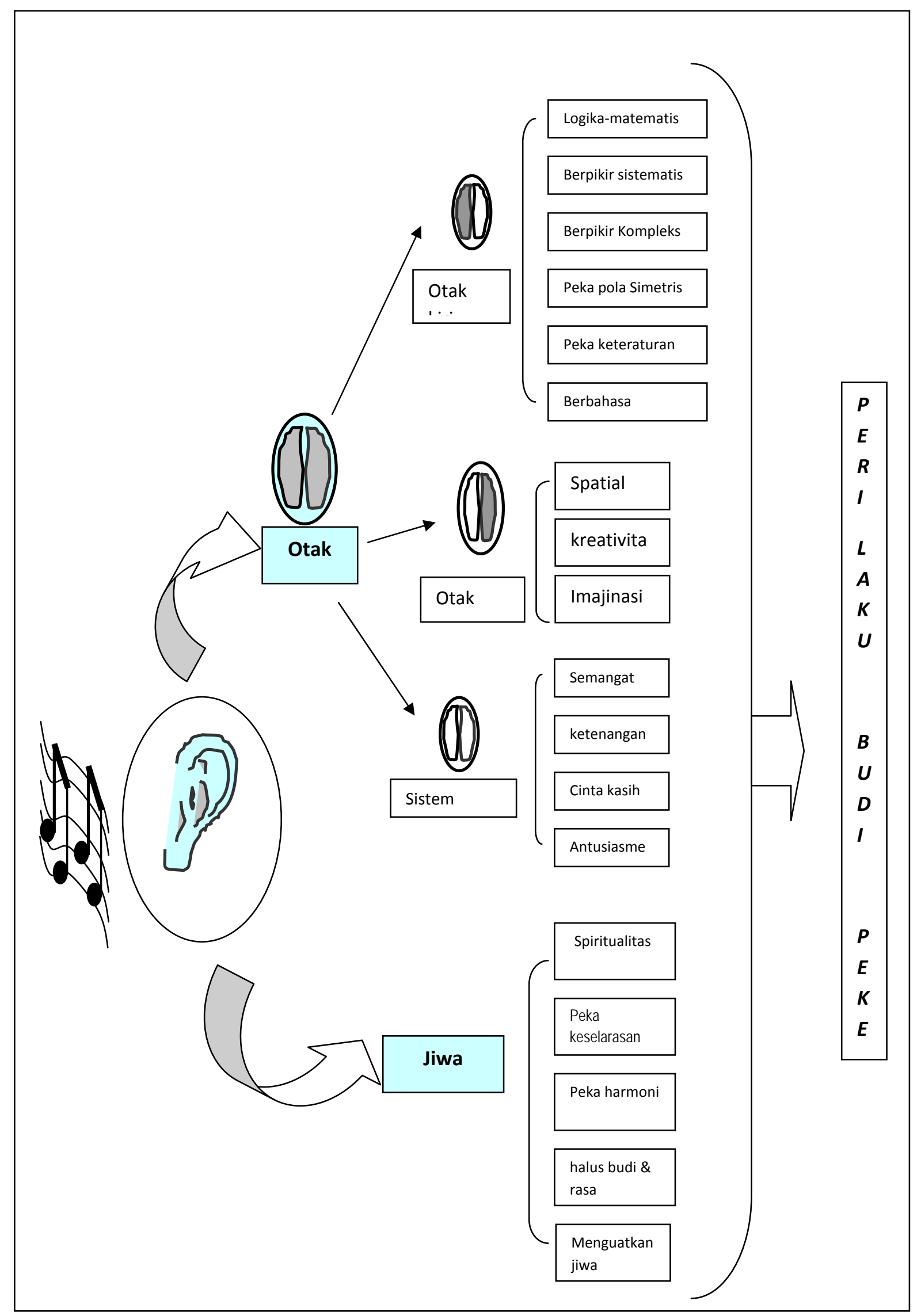

Gambar 2. Pengaruh musik terhadap fisik-mental (Rachmawati, 2005). 
2. Definisi Karsa

Menurut Kamus Besar Bahasa Indonesia (2008), karsa dapat diartikan sebagai: 1) daya (kekuatan) jiwa yang mendorong makhluk hidup untuk berkehendak; 2) kehendak atau niat. Jika kita memahami makna karsa, terdapat padanan yang maknanya hampir sama dengan karsa yaitu motivasi. Beberapa arti motivasi menurut para ahli antara lain sebagai berikut.

a. Motivasi berasal dari kata 'motif' yang artinya daya upaya yang mendorong seseorang untuk melakukan sesuatu. Motif dapat dikatakan sebagai daya penggerak dari dalam dan di dalam subjek untuk melakukan aktivitasaktivitas tertentu demi mencapai suatu tujuan (Sardiman, 2009). Hal ini senada dengan ungkapan Usman (2002), motif adalah daya dalam diri seseorang yang mendorongnya untuk melakukan sesuatu, atau keadaan seseorang atau organisme yang menyebabkan kesiapannya untuk memulai serangkaian tingkah laku atau perbuatan.

b. Motivasi adalah suatu proses untuk menggiatkan motif-motif menjadi perbuatan atau tingkah laku untuk memenuhi kebutuhan dan mencapai tujuan, atau keadaan kesiapan dalam diri individu yang mendorong tingkah lakunya untuk berbuat sesuatu dalam mencapai tujuan tertentu (Usman, 2002:2829).

c. Motivasi merupakan perubahan energi dalam diri seseorang yang ditandai dengan munculnya 'feeling' dan didahului dengan tanggapan terhadap adanya tujuan (Mc. Donald, 1959 dalam Sardiman, 2009).

d. Makmun (2005) memberikan dua definisi motivasi yakni (1) suatu kekuatan (power) atau tenaga (forces) atau daya (energy), (2) suatu keadaan yang kompleks (a complex state) dan kesiapsediaan (preparatory set) dalam diri individu (organisme) untuk bergerak (to move, motion, motive) ke arah tujuan tertentu, baik disadari maupun tidak disadari.

3. Definisi Cipta

Makna cipta menurut Kamus Besar Bahasa Indonesia (2008) adalah kemampuan pikiran untuk mengadakan sesuatu yang baru; angan-angan yang kreatif; adapun men·cip·ta $\mathrm{V}$ memusatkan pikiran (angan-angan) untuk mengadakan sesuatu: untuk dapat cerita yg baik, diperlukan fantasi; men·cip·ta·kan 1) menjadikan sesuatu yang baru tidak dengan bahan: Allah bumi dan langit; 2) membuat atau mengadakan sesuatu dengan kekuatan batin: menurut cerita, yang Candi Prambanan ialah Bandung Bondowoso; 3) membuat (mengadakan) sesuatu yang baru (belum pernah ada, luar biasa, lain dari yang lain): melalui perundingan kita dapat suasana saling mengerti; 4) membuat suatu hasil kesenian (seperti mengarang lagu, memahat patung): yang lagu Indonesia Raya adalah W.R. Supratman.

Jika kita deskripsikan dalam bentuk gambar, adalah sebagai berikut.

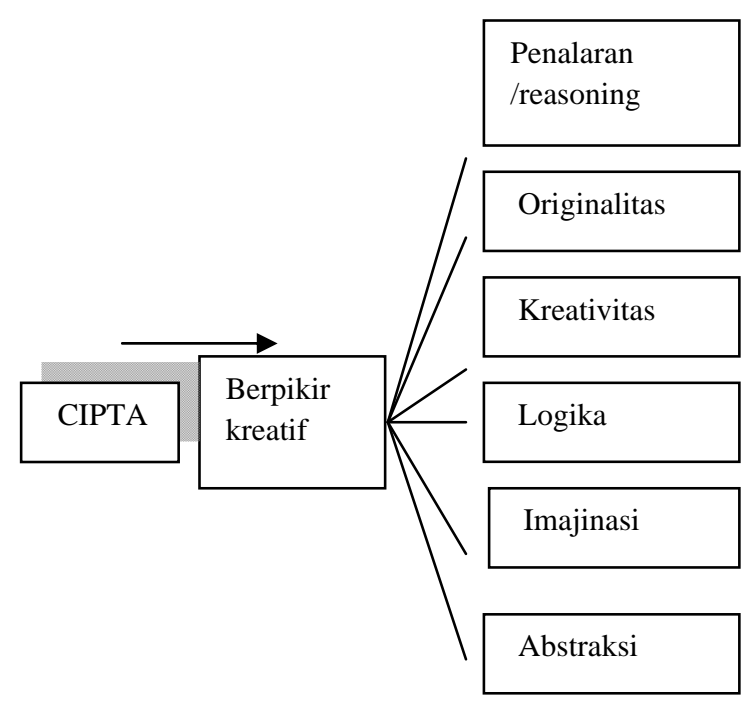

Gambar 3. Makna Cipta. 
4. Definisi Karya

Wiryomartono (2001) menjelaskan bahwa pengertian berkarya bagi orang Jawa erat kaitannya dengan pengertian "memayu ayuning bawana" artinya tidak ada maksud berkarya yang tidak menghaturkan keindahan dunia. Sedangkan pengertian karya menurut Kamus Besar Bahasa Indonesia (2008) adalah: 1) pekerjaan; 2) hasil perbuatan; buatan; ciptaan (terutama hasil karangan): novel $\mathrm{Be}-$ lenggu merupakan -- terkenal Armijn Pane; Lebih lanjut Wiryomartono (2001) mengungkapkan pengertian yang identik dengan karya intinya adalah perbuatan, tindakan, pekerjaan, urusan, tugas, pertunjukan, pesta, motif dan maksud. Sedangkan mahakarya mencakup pengertian-pengertian menghasilkan sesuatu, membuat perwujudan, melaksanakan tugas, menyelesaikan pekerjaan, mengolah sesuatu, memperhalus sesuatu, dan mengusahakan sesuatu.

\section{Pengembangan Model RKCK (rasa-karsa-cipta-karya)}

1. Prinsip model pembelajaran RKCK

a. Bersifat menyeluruh

Model pembelajaran RKCK bersifat holistik dan integratif, artinya model ini akan mengaktifkan aspek fisik dan mental, afeksi dan intelektual, yang disertai action, atau munculnya tindakan.

b. Problem based learning

Pelaksanaan Model RKCK selalu diawali dengan "problem base" yang disampaikan kepada para siswa.

c. Membangun kesadaran

Dari permasalahan yang diajukan, para siswa akan mendapatkan stimulasi afeksi dan didorong untuk memiliki untuk memiliki kedasaran terhadap persoalan yang dihadapi.

d. Mendorong motivasi intrinsik
Setelah muncul kesadaran, para siswa akan dibimbing untuk menemukan sendiri motivasi intrinsik dalam dirinya.

e. Membangun gagasan

Dengan munculnya motivasi intrinsik, maka diproyeksikan mereka akan membangun gagasan untuk menyelesaikan permasalahan.

f. Menciptakan karya

Dengan gagasan tersebut, para siswa diberi tugas untuk mengaktualisasikan gagasannya ke dalam bentuk tindakan nyata.

2. Bentuk Pemodelan "Model Pembelajaran RKCK"

Sebagai gambaran awal rumusan model pembelajaran pendidikan anak usia dini RKCK adalah sebagai berikut.

a. Tahap aktivasi rasa

Pada tahap aktivasi rasa, guru dapat melakukan pendekatan sebagai berikut.

1. Anak diajak untuk mengalami secara konkrit sebuah topik pembelajaran. Pengalaman konkrit ini harus mengaktifkan keseluruhan panca inderawinya (mata, telinga, hidung, lidah, kulit) sehingga terjadi pencerapan pengetahuan inderawi secara utuh (hal ini sesuai dengan definisi rasa secara fisik)

2. Anak diajak untuk menghayati sebuah persoalan atau dengan kata lain menghayati "problem base" yang secara nyata mereka lihat. Problem yang diangkat sebagai topik dapat dilihat langsung atau melalui tayangan film. Mereka dilatih untuk berempati dan mengemukakan pemikirannya tentang persoalan tersebut. Pada tahap ini guru dapat membantu anak dengan mengajukan pertanyaan: 
a). Bagaimana menurutmu tentang permasalahan tersebut?

b). Bagaimana perasaanmu jika kejadian/masalah tersebut menimpamu?

c). Apa yang kau rasakan ?

d). Bagaimana perasaanmu?

3. Guru meminta anak untuk menceritakan tanggapan mereka terhadap topik melalui gambar, puisi atau pun lagu.

b. Tahap membangun karsa (motivasi)

Pada tahap karsa, guru dapat membangkitkan motivasi anak didik dengan mengajak berdialog dan mengajukan pertanyaanpertanyaan seperti, apa yang dapat kita lakukan untuk membantu mengatasi masalah tersebut?

c. Tahap mencipta (mengembangkan gagasan)

Pada tahap mencipta atau mengembangkan gagasan, guru dapat memberikan stimulasi dengan mengajukan pertanyaan berikut:

1. Apa saja yang dapat di lakukan untuk membantu menyelesaikan masalah tersebut?

2. Pilihlah salah satu penyelesaian yang dapat kamu lakukan!

3. Apa rencanamu untuk mewujudkan gagasan (penyelesaian masalah) tersebut?

4. Buatlah rencana untuk mengatasi masalah tersebut

d. Tahap implementasi gagasan (karya)

Pada tahap implementasi gagasan atau melakukan tindakan dan membuat karya, guru dapat me- mbantu anak untuk terjun langsung ke lapangan dan mengimplementasikan solusi yang telah direncanakan, dipilih dan dirancang hingga proses implemetasi. Jika diilustrasikan, maka model pembelajaran RKCK dapat dilihat melalui gambar berikut:

\section{PEMODELAN “BINTANG”}

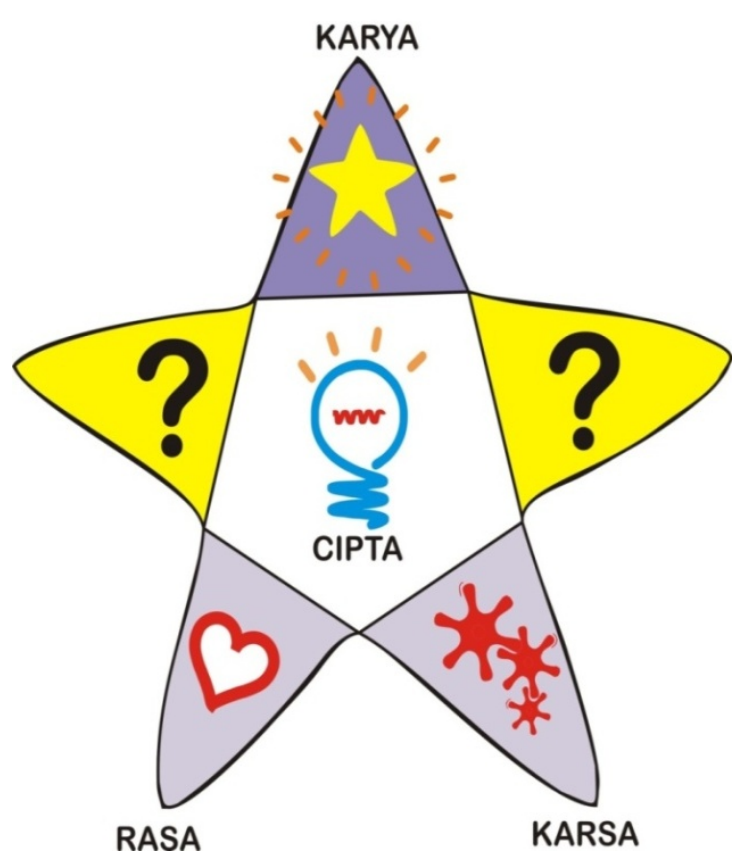

Gambar 4. Model Pembelajaran RKCK (rasa karsa cipta karya)

\section{Penutup}

Artikel ini merupakan sebuah gagasan awal dari model pembelajaran berbasis RKCK yang sedang dikembangkan. Dengan sifatnya yang holistik dan integratif, model ini diharapkan dapat menjadi alternatif solusi dalam permasalahan "ketidakseimbangan pendidikan" yang banyak dikeluhkan oleh para pakar pendidikan. Selain itu model pembelajaran RKCK diharapkan dapat menjadi preliminary research dalam meremajakan kembali berbagai falsafah luhur yang telah ada dalam jiwa bangsa Indonesia, yang kemudian dibangun kembali dan 
diadaptasikan kedalam bentuk model pembelajaran khas Indonesia, yang tidak kalah mutakhir dengan teoriteori barat.

\section{Daftar Pustaka}

Amstrong, Thomas. 2003. Setiap Anak Cerdas. Panduan Membantu Anak Belajar Dengan Memanfaatkan Multiple Intelligence. J akarta : Gramedia

Dewantara, Ki Hajar. 1962. Bagian Pertama: Pendidikan. J ogjakarta :Pertjetakan Taman Siswa

Given, Barbara K. 2007. Brain Base Teaching. Bandung: Kaifa

Tn. 2008. Kamus Besar Bahasa Indonesia. J akarta : Pusat Bahasa Departemen Pendidik Nasional.Tersedia Http:/ / Pusatbahasa.Diknas.Go. Id/Kbbi/Index.Php. Diunduh tanggal 11 Maret 2010

Makmun, Abin Samsudin. 2006. Psikologi Pendidikan. Bandung: Rosda Karya.

Nurgiyantoro, Burhan. 1985. Dasardasar Pengembangan Kurikulum Sekolah. Yogyakarta : BPFE

Rachmawati, Yeni. 2005. Musik Pembentuk Budi Pekerti. Yogyakarya: J alasutra

Sardi, Martin. 1985. Pendidikan Manusia. Bandung: Alumni

Sardiman, A.M. 2009. Interaksi dan Motivasi Belajar Mengajar. J akarta: RajaGrafindo Persada
Sedyawati, Edi. 2008. Keindonesiaan dalam Budaya. Jakarta: Wedatama Widya Sastra.

Sugiyono. 2008. Metode Penelitian Pendidikan. Bandung: Alfabeta

Sindhunata. 2000. Membuka Masa Depan Anak-Anak Kita, Mencari Kurikulum Pendidikan Abad XXI. Yogyakarta : Kanisius

Sukmadinata, Nana Syaodih. 2009. Metode Penelitian Pendidikan. Bandung: Rosda Karya.

Surakhmad, Winarno. 2009. Pendidikan Nasional .Strategi dan Tragedi. Jakarta: PT Kompas Media Nusantara.

Tanuwidjaya, Zamzam A.J. 2000. Jurnal Psikologi No.01 Volume 1. Bandung: PITC

Usman, M.U. 2002. Menjadi Guru Profesional. Bandung: PT Remaja Rosdakarya.

Wiryomartono, Bagoes P . 2001. PijarPijar Penyingkap Rasa. J akarta: Gramedia. 